\title{
SELECTED ASPECTS IN EDUCATIONAL RELATIONSHIPS
}

\author{
Lucie Flekačová, Monika Smolíková, \& Dita Finková \\ Institute of Special Education Studies, Palacký University Olomouc (Czech Republic)
}

\begin{abstract}
The objective of the present paper supported by the Student Grant Competition at Palacký University Olomouc (Research on inclusion of pupils and students with special needs, IGA_PdF_2018_014) was to analyse, identify and determine the aspects of the relationships between educational professionals. The demand for the data resulted from a quantitative research study undertaken in 2017 in the framework of researching inclusion among persons with special needs.

The basic usable data were obtained by means of a qualitative research approach focusing on primary school educational staff and analysing professional relationships between two groups - teachers and assistant teachers. The research was based on semi-structured interviews and included 21 respondents in each category. The research was carried out from April 2018 to November 2018 and was based on the reflection of the two occupational groups consisting of the employees of Palacký University Olomouc. In the framework of these focus groups, the basic interview topics were defined that focused on mutual communication, personal relationships, administration, and teaching organization.

The results of the research suggested the importance of reflection in the relationship between educational professionals, which is based on the requirement for a clear definition of the competences of both target groups both in terms of teaching organization and job content, especially in the case of assistant teachers. This aspect is also crucial in terms of administration, where there is a discrepancy between the teachers' own needs and assigning administrative responsibility to their assistant teachers, who seldom fulfil these duties. Despite the great variability and complexity of the data collected, the needs of both groups were identified. Both groups assess their daily communication in a positive way, but the research also suggests that the system of education lacks sufficient time for a deeper analysis of the teaching process; and therefore, both groups use alternative means of communication, even after working hours. The structure of the educational process highlights a high degree of adaptability of the participants and significantly affects the feeling of own competency and indispensability in the educational process. Both groups prefer communication based on partnership, which requires specific favourable conditions and sufficient time.

The results indicate the need for a deeper analysis of the relationships in a broader context of the school environment, which would include both the attitude of the leading employees and other staff involved in the process of inclusive education.
\end{abstract}

Keywords: Inclusion, assistant teacher, special education, primary school, relationships.

\section{Introduction}

Inclusive education of pupils and students with special needs is the focus of many research studies. In previous years, some great developments have been achieved. In the Czech Republic, segregated education of learners with special educational needs is being transformed to achieve integration in mainstream education (Michalík et al., 2018). An example of a document that supports inclusion is the National Programme for the Development of Education in the Czech Republic (the so-called White Paper, 2001), the content of which provides for an equal access to education for all, including the effort to improve the position of educational staff. A previous research (Michalík et al. 2018) claims that there are different attitudes to the ongoing reform of inclusive education in the Czech Republic, especially on the part of special education teachers, whose opinion about inclusion is rather negative in comparison with other teachers.

In the Czech Republic, the position of an assistant teacher has developed since 1993 and can be considered a relatively new concept (Nová škola o.p.s., 2003). In terms of legislation, the job content of assistant teachers is stipulated by Section 5 Assistant teacher, Decree No. 27/2016 Coll. effective of 1 November 2018. It is necessary to focus not only on the job content but also on the aspects that affect it, and the influence of the interaction between the two actors of the educational process - assistant and teacher. 


\section{Aim of the study - research questions}

The main objective of the research study was to identify, analyse and describe the current relationship between educational professionals. The main research question was as follows: What is the perception of educational staff of mutual professional relationships? The research study focused on the opinions and attitudes of assistant teachers and teachers in the area of mutual communication, professional relationships, administration, and teaching organization.

\section{Methodology}

The methodology is based on the results of a quantitative research study exploring the attitudes of educational staff to selected aspects of joint education (Michalík et al. 2018). To achieve the research objective, the qualitative research approach was chosen. The research used qualitative data collection methods by means of semi-structured interviews. This method of data collection involved a research sample of 21 teachers and 21 assistant teachers. The decision concerning the sample of respondents was based on a meeting of two focus groups, which was attended by primary school teachers as well as academic professionals. Based on several meetings of the focus groups, the inclusion criteria concerning the sample of respondents were specified as follows: primary school teachers and assistant teachers, joint teaching experience of at least 1 year. The teacher focus groups selected three themes for the semistructured interviews: communication and personal relationships, administration, and teaching organization. For each theme, open-ended question were formulated, the content of which was based on applicable norms and legislative documents. The researcher was defined as a visitor, the researcher's name was known to the participants, and the researcher visited the respondents on a regular basis in order to achieve the objective of the research (Švaříček et al., 2014).

The interviews were voice-recorded and transcribed. Data analysis was performed by means of open coding using the RQDA project (R Core Team, 2019). For a qualitative analysis, Majerová (2016) also recommends the RQDA project, which she combines in her paper with other approaches. Using a special software tool, the text was broken to units and each unit was assigned with a specific code. After that the codes were categorized. The data were classified and evaluated using a content analysis approach.

\section{Data analysis and results}

\subsection{Mutual communication}

The process of data analysis was based on the communication partners preferred by the actors involved - teachers and assistant teachers. The total number of codes for this category shows a higher number of communication partners of teachers ( 13 codes) compared with assistant teachers ( 9 codes). Both groups are dominated by communication with teachers (teachers communicating with colleague teachers). As far as other preferences in the process of communication are concerned, teachers communicate most frequently with the parents of children with special educational needs (referred to as SEN), followed by school management, and finally assistant teachers. From the perspective of assistant teachers (referred to as AT), the most frequent communication takes place with teachers, followed by parents of children with SEN, and other ATs. In addition to joint communication actors, who for both groups of the research sample include educational counsellors, special education teachers, psychologists, and prevention methodologists, teachers often communicate with employees of special education centres, educational and psychological counselling centres, universities, and the public.

The interview analyses below will only include the teacher-AT interaction. The three aspects that proved to be crucial for both groups were diversity, flexibility, and frequency of communication. All these attributes determine the quality of mutual communication. For teachers, the most important aspect is flexibility, followed by frequency, and diversity. From the perspective assistant teachers, a crucial role is played by communication with teachers.

In the context of the frequency of communication, teachers prefer everyday communication (usual situations), communication once a week (learning content), communication once a month (thematic teaching units). From the perspective of assistant teachers, this area is significant and is mostly associated with situational matters throughout the whole day; a deeper analysis of a problem could take place once a week or once every two weeks. Communication flexibility is a crucial quality-affecting factor from the perspective of teachers; they mostly assess this aspect in a positive way, negative assessment is associated with the arrangement of ATs' working time as defined by the law.

The analysis further suggests that the need for communication correlates with the rigid assessment of mutual communication by teachers. In terms of content, teachers lack a deeper insight into 
the system of education or specific subjects in the context of time arrangement of the school year. This need is more pronounced at the beginning of the school year.

As far as the content of communication is concerned, ATs prefer to communicate about the organization of the teaching process, while teachers of the same level emphasise communication about the organization of the teaching process and about learners with SEN. The results of a content analysis of the interviews suggests that ATs prefer verbal communication (oral, e-mail, phone, social networks). Teachers also prefer verbal communication (oral communication, text messages, Skype or WhatsApp). As far as communication mediators are concerned, the respondents would appreciate professionals from the Ministry of Education and counselling centres (educational and psychological counselling centres, special education centres), the teachers would also appreciate interventions by the headteacher, school psychologist/special education teacher, or a different experienced AT. For ATs the crucial person for establishing communication is the headteacher, prevention methodologist, or a different experienced AT.

\subsection{Professional relationships}

A crucial aspect in this area is the dominant position in the class. According to teachers, some ATs have a dominant position in the educational process, but this may be desirable in relation both to the teacher and the learners, provided that the boundaries between the teacher and AT were clearly defined at the beginning of their cooperation. In the event that AT was previously a teacher/headteacher and was mostly dominant, teachers assess this dominance as a negative aspect.

Some teachers emphasise a low degree of motivation on the part of ATs and define their desirable behaviour (ability to balance conflict situations, ability to temporarily substitute the teacher in the system of education, independence, empathy, tolerance, communicativeness, precision, inventiveness, creativity, flexibility, own initiative, and teamwork). Teachers would like to cooperate with ATs to maintain order in the classroom and to ensure the behavioural component in the system of education.

A positively evaluated aspect was mutual assessment of employees, which also includes the area of organizational matters and can be used as a prevention of problematic relationships in the workplace.

Teachers' definitions of a professional relationship differ. The analysis of the interviews suggest that a professional relationship can be problematic, friendly (trouble-free), or partnership-based (with a detachment) in both groups of respondents. In the case problematic relationships, teachers do not see any importance or contribution of ATs in the class, but not in terms of the system but rather in the context of ATs' qualities and behaviour. The presence of AT in the class is burdensome and is considered "extra work". All these teachers tried to change ATs' behaviour but gave up after repeated failure. They believe that a good relationship should be based on a clearly defined job content and adequate rules to be checked by leading employees. A relationship based on partnership (with a detachment) is defined as a balanced relationship with peer support, with no significant friendship tendencies, and of a highly professional nature. A friendly relationship is defined as one which is trouble-free, helpful, and respectful. According to some teachers (especially women), a major role is played by ATs' opinions and perspectives in life and their general attitude to life. A content analysis of the interviews with ATs suggests a dominant need for friendly professional relationships with teachers, which is considered a fundamental aspect of a quality relationship in the workplace. In the case of ATs, this relationship is highly appreciated especially because the personal/private aspect of communication is involved. Similarly to the group of teachers, one of the types is a partnership-based relationship (with a detachment), which is according to ATs enriching, respectful, intimate, but remains professional. The other type is a problematic professional relationship, which is based on a dominant position of the teacher, which ATs believe is associated with ATs' level of education. The desirable qualities and behaviour of teachers are based on directiveness in the teaching process, ability of good planning, optimistic tuning, openness, frankness, and ability to enrich both children and ATs. According to ATs, the dominant factor affecting the relationship is the degree of certainty in the context of leadership, rules and expectations on the part of teachers. This factor is significant at the beginning of the school year especially for beginning ATs.

\subsection{Administration and teaching organization}

A total of 13 teachers reported that ATs helped with administration, in all of these cases ATs' help was assessed in a positive way. In terms of content, this particularly included cooperation in the development/evaluation of individual education plans, adding information in relevant documents, and making records/questionnaires about the child. Some teachers appreciate when ATs are willing to help with correcting exercise books, copying materials, and producing the final assessment of learners with SEN. However, none of the teachers make ATs fully responsible for the assessment of learners with SEN. ATs' help in the area of administration is definitely not commonplace; 11 teachers state they are not helped with administration. If ATs keep records about children with SEN, teachers appreciate it, but some of them keep separate records for their own needs. Teachers' responses suggested a high degree of 
responsibility for the educational process and assessment, with a certain reluctance to transfer the responsibility to ATs. ATs confirm the teachers' statement and state that they participate in learner assessment especially through discussion or presenting their opinions about the progress of learners with SEN, but the final assessment is the responsibility of the teacher. ATs keep assistant logs in order to keep important information about learners with SEN; at the same time these logs are used for communication between AT and the child's parents.

From the perspective of teachers, the crucial aspects affecting teaching organization include methodological guidance (especially methodological guidance of ATs), sharing of roles in the context of assigning responsibility, defining rules, AT job content, support provided by the management, preparation for classes and the educational process, and last but not least supervision. According to teachers, the distribution of roles in the classroom is rather unbalanced; ATs often appear to be in a submissive position. This factor is very closely related to the area of assigning responsibility. Those teachers who believe in evenly distributed responsibility for the educational process and organization have assigned a degree of responsibility for children with special educational needs to ATs. A balanced level of responsibility is reflected especially in the organizational structure of lessons but also outside the classroom. Those teachers who believe in balanced responsibility state that they can rely on ATs (this is the main attribute affecting the process of assigning responsibility to ATs). At the same time, this aspect is reflected in the structure of the educational process, where ATs are often identified as teachers (children address them as teachers). On the contrary, in cases where the degree of responsibility is assessed as unbalanced, ATs usually break the rules, but this is consistent with the dominant teacher position in the process of education. There is a certain degree of reluctance to assign responsibility to ATs in order to maintain the leading classroom position and a high degree of responsibility for all children (including those with special educational needs). The degree of responsibility is associated with a clear definition of boundaries, which according to teachers lies within their competence.

The assessment also focused on teachers' perspectives of ATs' job content. The responses suggest that in teaching organization ATs help with setting classroom rules in order to maintain discipline, prepare teaching aids, pay individual attention to a specific child/children, and exceptionally handle the whole class. However, there are also situations in which assistant teachers are called by school management to carry out different activities outside the classroom. Some teachers are not sure about ATs' job content. According to ATs, besides their own work they help teachers with scanning and copying of documents, make teaching aids, help with weaker students in the class, and exceptionally substitute teachers in their educational role. An analysis of ATs' responses suggests that although substituting the teacher role is acceptable, they would appreciate a clear definition of the roles and activities of assistant teachers.

ATs' support in lesson preparation is not provided to all teachers. Those teachers who ask ATs for help in lesson preparation are grateful and assess ATs' contribution in a positive way. In the event that ATs are not involved in lesson preparation, it is very often the teachers' decision, who often consider ATs unreliable, non-cooperating, and not obeying the rules. Regarding this fact, the researchers included a question on the preparation for the educational process in the context of the beginning of the school year. 11 teachers were actively involved at the time of the survey. Most of them also commented on the content and form of this preparation. The analysis suggests that this primarily includes the definition of organizational matters and setting of professional relationships (definition of expectations, familiarization). It is inopportune for teachers if ATs come on the first day of the school year. Such situation becomes difficult for teachers, including feelings of uncertainty. A suitable period for establishing teacher-AT cooperation seems to be the preparatory week; often more time is needed. At the same time, some teachers need to see ATs working with children during the previous school year. According to ATs, a convenient time for defining their role and job content is during the preparatory stage (i.e. at the beginning of the school year). This need is also based on concerns and insufficient readiness on the part of ATs for specific difficulties of learners with SEN, at this stage ATs would appreciate a meeting with the parents of the child with SEN together with the school management. The purpose of the preparatory stage should be to learn about the class and organizational structure of the school. Some also believe that the education of ATs (specialized courses) is insufficient in the Czech Republic, especially in the case of children with complicated diagnoses (e.g. autism spectrum disorders).

Feedback in the area of organization and education is a natural aspect for both teachers and ATs. There are only few areas where teachers and ATs show insufficiencies in terms of feedback (this includes especially reflection of positive feedback on the educational process). Teachers show a positive attitude to feedback, they consider it a natural part of their educational work. Both ATs and teachers prefer the verbal form of communication and e-mail communication. For both teachers and ATs, an appropriate frequency is after each lesson (if there are no serious problems). If there are no significant problems, both ATs and teachers agree that the frequency of feedback regarding a deeper analysis of teaching 
organization, mutual self-reflection, and searching for new ways in education should be on average once a month. If there are difficulties, both groups prefer communication as needed - if possible immediately in order to find a solution to the problem.

\section{Conclusion}

A significant aspect in the context of educational relationships seems to be helping teachers with establishing initial communication. Also, the preparatory stage of the educational process is of great importance. There is a frequent requirement for a communication mediator from outside (for example from counselling centres or the Ministry of Education).

Both categories of respondents prefer the verbal form of communication (oral or e-mail).

The respondents prefer a professional relationship with a high degree of friendly personal ties; both groups consider this relationship the basis of high-quality cooperation.

The area of organization and administration suggests a degree of willingness on the part of ATs to cooperate with teachers. On the other hand, there is a concern about the dominant position of the teacher, who strictly controls the process of education. According to teachers, assigning the responsibility for education to ATs is closely associated with clearly defined qualities of assistant teachers. This reluctance to some extent correlates with a conscious need of teachers to maintain leadership in the class.

Some teachers and ATs suggest that they do not have a clear idea about ATs' job content including the definition of direct and indirect working time and its use.

Feedback related to the area of communication and teaching organization focuses rather on negative phenomena (problems in teaching organization or difficulties of children with SEN); positive feedback is not usual although it should be used; the respondents tend to prefer negative feedback. In the organization of the educational process, the preparatory stage is of special importance at the beginning of the school year; in the course of the school year and at the end the importance decreases.

\section{Acknowledgments}

This study is the result of a scientific research project supported by the following IGA project: IGA_PdF_2018_014 "Research on inclusion of pupils and students with special needs" carried out at Palacký University Olomouc.

\section{References}

Majerová, H. (2016). Vnímání osoby se zrakovým postižením v kontextu specifik představivosti. Olomouc: Univerzita Palackého v Olomouci.

Michalík, J., Baslerová, P., \& Růžička, M. (2018). Postoje pedagogických pracovníků k vybraným aspektưm společného vzdělávání. Olomouc: Univerzita Palackého v Olomouci.

MŠMT. (2018). Vyhláška č. 27/2016 Sb., o vzdělávání žáků se speciálními vzdělávacími potřebami a žáků nadaných, ve znění účinném od 1. November 2018. Retrieved from: http://www.msmt.cz/dokumenty-3/vyhlasky-ke-skolskemu-zakonu.

Národní program rozvoje vzdělávání v České republice: Bílá kniha. (2001). Praha: Ústav pro informace ve vzdělávání.

Nová škola o.p.s.. (2003). Spolupráce s vychovatelem-asistentem učitele aneb jak ve škole vytvořit tandem. [accessed 2019 01-27]. Retrieved from: http://asistentpedagoga.cz/assets/content/files/prirucka_tandem.pdf

R Core Team (2019). R: A language and environment for statistical computing. (R Version 3.5.2) [software], R Foundation for Statistical Computing: Vienna, Austria. [accessed 2019-01-26]. Retrieved from: https://www.R-project.org/.

Švaříček, R., \& Šed'ová, K. (2014). Kvalitativní výzkum v pedagogických vědách (2nd ed.). Praha: Portál. 